\title{
Anaphylaxis caused by artisanal honey in a child: a case report
}

\author{
Margherita Di Costanzo ${ }^{1,2^{*}}$, Nicoletta De Paulis ${ }^{1}$, Silvia Peveri ${ }^{3}$, Marcello Montagni ${ }^{3}$, \\ Roberto Berni Canani ${ }^{2,4,5,6}$ and Giacomo Biasucci ${ }^{1}$
}

\begin{abstract}
Background: Honey is a rare cause of food allergy, especially in children, but it can cause severe systemic allergic reactions. In the pediatric age group, only a few cases have been reported in the literature. Honey allergy may be caused by pollen content or bee-derived proteins. A role for Compositae has been suggested among pollen allergens. Allergology workup of a patient with suspected honey allergy is not well defined. Here we describe a rare case of anaphylaxis in a 5-year-old boy, sensitized to Compositae pollen (ragweed and mugwort), after the ingestion of artisanal honey.

Case presentation: The Slavic patient was referred to our hospital emergency department for generalized urticaria and breathing impairment. All the symptoms occurred approximately 30 minutes after the ingestion of a meal containing salmon and artisanal honey. The allergology workup revealed that a skin prick-by-prick test with the implicated artisanal honey was positive, while a variety of different commercial honey and salmon products yielded negative results. Skin prick test and serum-specific immunoglobulin E (lgE) results were also positive for Compositae pollen (ragweed and mugwort). Patients sensitized to weed pollens who ingest bee products may experience an immediate allergic reaction because of the cross-reaction between weed pollens and Compositae bee product pollen. In this case, primary sensitization may be due to airborne Compositae pollen. Commercial honey is heavily processed due to pasteurization and filtration, which removes most of the pollen. These observations highlight the role of Compositae pollen in the observed allergic reaction and suggest that the different pollen content in the artisanal honey relative to commercial honey was responsible for the allergic reaction in our patient.

Conclusions: This is the first reported pediatric case of honey-induced anaphylaxis in a child under 6 years of age sensitized to Compositae pollen. Pediatricians should be aware of the potential risk of severe allergic reactions upon ingestion of honey and bee products, especially in patients sensitized to weed pollens. To diagnose honey allergy, obtaining a proper clinical history is essential. In addition, skin prick-by-prick tests are helpful, and may represent a simple method to screen for honey allergy in patients sensitized to Compositae pollen, in light of the potential risk.
\end{abstract}

Keywords: Food allergy, Honey, Anaphylaxis, Compositae pollen, Case report

*Correspondence: M.DiCostanzo@ausl.pc.it

1 Department of Pediatrics and Neonatology, Guglielmo da Saliceto Hospital, Piacenza, Italy

Full list of author information is available at the end of the article

\section{Background}

Food allergy is a common condition in childhood. Recent studies have suggested that the natural history of food allergy has changed in recent decades, with an increased prevalence, severity of clinical manifestations, and risk of persistence until later ages [1-3]. Honey allergy is a rare form of food allergy, especially in the pediatric age group. So far, only a few pediatric cases have been reported in original author(s) and the source, provide a link to the Creative Commons licence, and indicate if changes were made. The images or other third party material in this article are included in the article's Creative Commons licence, unless indicated otherwise in a credit line to the material. If material is not included in the article's Creative Commons licence and your intended use is not permitted by statutory regulation or exceeds the permitted use, you will need to obtain permission directly from the copyright holder. To view a copy of this licence, visit http://creativecommons.org/licenses/by/4.0/. The Creative Commons Public Domain Dedication waiver (http://creativeco mmons.org/publicdomain/zero/1.0/) applies to the data made available in this article, unless otherwise stated in a credit line to the data. 
the literature. Although it is a rare condition, it is important because ingested honey can cause from mild to severe allergic reactions, such as anaphylaxis [4]. Additionally, due to the diverse health benefits of honey and bee products such as propolis and royal jelly [5], increasing honey consumption in health food may increase the incidence of honey-related allergic reactions. Several studies have been performed to identify specific antigenic structures of honey [6]. Honey consists of flower nectar, pollens, and components derived from bees [7]. Honey allergy may be caused by pollen content (especially Compositae pollen) or bee-derived proteins. Also, royal jelly, a secretion of worker honey bee venom, is reported to cause anaphylaxis and asthma exacerbation [8]. Allergology workup of a patient with suspected honey allergy is not well defined. Herein, we report a rare case of anaphylaxis in a patient of pediatric age, caused by an artisanal honey product in a 5-year-old boy sensitized to Compositae pollen.

\section{Case presentation}

The patient was a 5-year-old Slavic boy affected by allergic rhinitis from the age of 4 years (sensitization for dust mite and Plantago lanceolata). His past medical history was unremarkable; in particular he had no personal previous history of food allergy or anaphylaxis. He attended nursery school. Familial history revealed that his father had seasonal allergic rhinitis.

The patient was referred to our hospital emergency department by the territorial emergency unit for generalized urticaria and breathing impairment (peripheral oxygen saturation was $93 \%$ on ambient air). All the symptoms occurred suddenly 30 minutes after the ingestion of a meal containing salmon and artisanal honey. The intake of other foods/juices, alcohol, or medications was not reported. Salbutamol with inhaler (four inhalations, equivalent to $400 \mu \mathrm{g}$ ) was administered in the ambulance. On admission, the physical examination revealed generalized urticaria and wheeze-bronchospasm in apyrexia. Peripheral oxygen saturation was $97 \%$ on ambient air, blood pressure was $100 / 65 \mathrm{mmHg}$, heart rate was 120 beats/minute, and respiratory rate was 28 breaths/ minute. He was afraid but alert and responsive (Glasgow Coma Scale: 15). Intravenous methylprednisolone (20 $\mathrm{mg}$, equivalent to $1 \mathrm{mg} / \mathrm{kg} /$ dose) and chlorpheniramine ( $5 \mathrm{mg}$, equivalent to $0.25 \mathrm{mg} / \mathrm{kg} / \mathrm{dose}$ ) were administered, and salbutamol with inhaler (four inhalations, equivalent to $400 \mu \mathrm{g}$ ) was repeated, with progressive and rapid resolution of cutaneous and respiratory symptoms.

The results of routine laboratory analyses on admission were within the normal range (see Table 1). Tryptase serum levels and specific food IgE tests were performed for egg $(0.31 \mathrm{kUA} / \mathrm{L})$, milk (0.67 kUA/L), shrimp (0.08
Table 1 Routine laboratory findings on admission

\begin{tabular}{|c|c|}
\hline White blood cells $\left(\times 10^{3} / \mu \mathrm{L}\right)$ & 10.99 \\
\hline Red blood cells $\left(\times 10^{6} / \mu \mathrm{L}\right)$ & 4.5 \\
\hline Platelets $\left(\times 10^{3} / \mu \mathrm{L}\right)$ & 287 \\
\hline Hemoglobin (g/dL) & 12 \\
\hline Hematocrit (\%) & 34.4 \\
\hline Neutrophils (\%) & 49.3 \\
\hline Lymphocytes (\%) & 39.7 \\
\hline Monocytes (\%) & 7.5 \\
\hline Eosinophils (\%) & 3.1 \\
\hline Basophils (\%) & 0.4 \\
\hline C-reactive protein (mg/dL) & 0.05 \\
\hline Glycemia (mg/dL) & 123 \\
\hline Urea $(\mathrm{mg} / \mathrm{dL})$ & 27 \\
\hline Creatinine (mg/dL) & 0.26 \\
\hline Sodium (mEq/L) & 136 \\
\hline Potassium (mEq/L) & 3.8 \\
\hline Chlorine (mEq/L) & 107 \\
\hline Calcium (mg/dL) & 9.27 \\
\hline Aspartate aminotransferase $(U / L)$ & 39 \\
\hline Alanine aminotransferase (U/L) & 15 \\
\hline
\end{tabular}

kUA/L), cod (0.11 kUA/L), gluten (0.27 kUA/L), lipid transfer protein (LTP) Pru p $3(0.12 \mathrm{kUA} / \mathrm{L})$, soy $(0.72$ kUA/L), grass pollen (16.5 kUA/L), Dermatophagoides pteronyssinus $(3.67 \mathrm{kUA} / \mathrm{L})$, ragweed $(7.93 \mathrm{kUA} / \mathrm{L})$, and mugwort ( $35.3 \mathrm{kUA} / \mathrm{L}$ ), using the ImmunoCAP (Thermo Fisher Scientific, Sweden). Levels $\geq 0.35 \mathrm{kUA} / \mathrm{L}$ were considered positive.

The reaction tryptase level was $6.63 \mu \mathrm{g} / \mathrm{L}$ (normal values $<11 \mu \mathrm{g} / \mathrm{L}$ ), whereas the post-reaction level, detected 24 hours after the allergic event, was $2.04 \mu \mathrm{g} / \mathrm{L}$. In the pediatric age group, tryptase reaction levels exceeding a threshold level of $2 \mathrm{ng} / \mathrm{mL}+1.2 \times$ (post-reaction tryptase level) may be very useful in establishing a diagnosis of anaphylaxis [9]. In our patient, the reaction tryptase level exceeded the threshold level of $4.18 \mu \mathrm{g} / \mathrm{L}$.

The test for serum IgE antibodies to bee venom yielded a weak positive result $(0.65 \mathrm{kUA} / \mathrm{L})$. However, his personal history was negative for bee stings, and sensitization to hymenoptera venom is frequently found in atopic and non-atopic subjects. In particular, in atopic patients, a high sensitization rate has been observed and could partially be explained by cross-sensitization between pollen and hymenoptera venom due to specific IgE to crossreactive carbohydrate determinants [10].

The patient was discharged after 24 hours of clinical observation in good condition and without drug therapy. At the time of hospital discharge, an allergology follow-up was scheduled for 2 weeks later. Skin prick tests with ragweed (Ambrosia artemisiifolia) and mugwort (Artemisia 
vulgaris) were positive, while prick-by-prick tests with salmon and peanut were negative. As for honey, prickby-prick test with the mixture of flower artisanal honey that the patient consumed before allergic reaction was positive. On the contrary, prick-by-prick test with a commercial flower honey mixture, Millefiori (a kind of honey frequently consumed in our country, obtained from foraging on Compositae), was negative. Positive (histamine) and negative (saline solution) controls were included. The reactions were read after 15 minutes and were positive if there was a wheal $3 \mathrm{~mm}$ or greater. Based on the patient's clinical history and allergy test results, we made a diagnosis of anaphylaxis induced by honey. An oral provocation test was not performed because of the personal recent history of anaphylaxis. The patient was informed of the honey allergy and the importance of honey avoidance. An adrenaline auto-injection kit $(0.15 \mathrm{mg})$ was prescribed and the patient was instructed on its usage. After a year of follow-up, he had been able to avoid honey and remained asymptomatic.

\section{Discussion and conclusions}

We report the first pediatric case of honey-induced anaphylaxis in a child under 6 years of age sensitized to Compositae pollen reported in the literature.

Anaphylaxis is a life-threatening allergic reaction, and it is important to confirm the etiology to prevent recurrence. Severe allergic reactions caused by honey are rare. In the literature, honey allergy is usually attributed to the pollen content. Honey contains significant amounts of pollens, and this accounts for the role of pollen allergens in allergic reactions to honey. The importance of pollen allergens is confirmed by their identification in immunoblotting studies [6]. However, the pollen content of honey depends on the location and the season when pollens are collected by honey bees [11]. The most common pollens responsible for the reactions are assumed to be those of the Compositae family.

Our patient had no previous history of anaphylaxis after a bee sting or food allergy. He had a personal clinical history of allergic rhinitis from the age of 4 years, with skin prick tests and serum-specific IgE initially positive to dust mite and Plantago lanceolata. After the allergic reaction with honey ingestion, the allergology workup (skin prick test and serum-specific IgE) also yielded positive results for Compositae pollen: ragweed (Ambrosia artemisiifolia) and mugwort (Artemisia vulgaris).

Moreover, we observed that the prick-by-prick test yielded a positive result for artisanal honey and negative result for commercial honey. Commercial honey is heavily processed due to pasteurization and filtration, which removes most of the pollen. These observations highlight the role of Compositae pollen in the observed allergic reaction and suggest that the different pollen content in the artisanal honey relative to the commercial honey was responsible for the allergic reaction in our patient.

Patients sensitized to weed pollens who ingest bee products (honey, royal jelly, bee pollen) may experience an immediate allergic reaction because of the crossreaction between weed pollens and Compositae bee product pollen [12]. In this case, primary sensitization may be due to airborne Compositae pollen.

It is known that patients with pollinosis may display clinical characteristics caused by allergy to certain fruits and vegetables, but the mean age for the beginning of allergic symptoms is usually adulthood, and clinical manifestations are generally mild such as oral allergy syndrome [13].

To the best of our knowledge, this is the first reported pediatric case of honey-induced anaphylaxis in a child under 6 years of age sensitized to Compositae pollen. With regard to bee products in pediatric patients, Martín-Muñoz et al. described a 4-year-old boy with allergic symptoms, but without anaphylaxis, immediately following ingestion of bee pollen as a food supplement [14]. Another case of honey-induced anaphylaxis was described in a 14-month-old boy, but in this case the authors found no sensitivity to pollens or bee venoms [15].

In conclusion, despite being a rarely observed condition, honey allergy has serious consequences, even in childhood. Allergic reactions to honey can be related to many factors, including pollens. Pediatricians should be aware of the potential risk of severe allergic reactions upon ingestion of honey and bee products, especially in patients sensitized to weed pollens. To diagnose honey allergy, obtaining a proper clinical history is essential. In addition, skin prick-by-prick tests are helpful, and may represent a simple method to screen for honey allergy in patients sensitized to Compositae pollen, in light of the potential risk.

\section{Acknowledgements}

The authors thank Dr. Eleonora Savi for the valuable advice provided for the study.

\section{Authors' contributions}

$M D C, N D C, S P, M M$, and GB contributed to the patient's management. MDC and NDC contributed to the conceptualization of the work; MDC, NDC, and MM drafted the manuscript; MDC, NDC, SP, MM, GB, and RBC critically revised the manuscript. All authors read and approved the final manuscript.

\section{Funding}

The authors declare that they have no sources of funding.

\section{Availability of data and materials}

The data sets used and/or analyzed during the current study are available from the corresponding author on reasonable request. 


\section{Declarations}

Ethics approval and consent to participate

Not applicable.

\section{Consent for publication}

Written informed consent was obtained from the patient's legal guardian for publication of this case report and any accompanying images. A copy of the written consent is available for review by the Editor-in-Chief of this journal.

\section{Competing interests}

The authors declare that they have no competing interests.

\section{Author details}

1 Department of Pediatrics and Neonatology, Guglielmo da Saliceto Hospital, Piacenza, Italy. ${ }^{2}$ Department of Translational Medical Science - Pediatric Section, University “Federico II", Naples, Italy. ${ }^{3}$ Department of Allergology, Guglielmo da Saliceto Hospital, Piacenza, Italy. ${ }^{4}$ ImmunoNutritionLab - CEINGE Advanced Biotechnologies, University “Federico II", Naples, Italy. ${ }^{5}$ Task Force on Microbiome Studies, University of Naples "Federico II", Naples, Italy. ${ }^{6}$ European Laboratory for the Investigation of Food-Induced Diseases, University of Naples "Federico II", Naples, Italy.

Received: 26 March 2020 Accepted: 24 March 2021

Published online: 14 May 2021

\section{References}

1. Loh W, Tang MLK. The epidemiology of food allergy in the global context. Int J Environ Res Public Health. 2018;15:2043.

2. Sicherer SH, Sampson HA. Food allergy: A review and update on epidemiology, pathogenesis, diagnosis, prevention, and management. J Allergy Clin Immunol. 2018;141:41-58.

3. Leung ASY, Wong GWK, Tang MLK. Food allergy in the developing world J Allergy Clin Immunol. 2018;141:76-8.

4. Vezir E, Kaya A, Toyran M, Azkur D, Dibek Mısırlıoğlu E, Kocabaş CN. Anaphylaxis/angioedema caused by honey ingestion. Allergy Asthma Proc. 2014;35:71-4.
5. Pasupuleti VR, Sammugam L, Ramesh N, Gan SH. Honey, propolis, and royal jelly: a comprehensive review of their biological actions and health benefits. Oxid Med Cell Longev. 2017:2017:1259510.

6. Bauer L, Kohlich A, et al. Food allergy to honey: Pollen or bee products? Characterization of allergenic proteins in honey by means of immunoblotting. J Allergy Clin Immunol. 1996;97:65-73.

7. Bousquet J, Campos J, et al. Food intolerance to honey. Allergy. 1984:39:73-5.

8. Katayama M, Aoki M, Kawana S. Case of anaphylaxis caused by ingestion of royal jelly. J Dermatol. 2008;35(4):222-4.

9. De Schryver S, Halbrich M, Clarke A, La Vieille S, Eisman H, Alizadehfar R, Joseph L, Morris J, Ben-Shoshan M. Tryptase levels in children presenting with anaphylaxis: Temporal trends and associated factors. J Allergy Clin Immunol. 2016:137:1138-42.

10. Bergmann-Hug K, Fricker M, Hausmann O, Helbling A, Jörg L. Sensitization to Hymenoptera venom in pollen allergic patients: Frequency and involvement of cross-reacting carbohydrate determinants (CCD). PLoS ONE. 2020;15:e0238740

11. Lau P, Bryant V, Ellis JD, Huang ZY, Sullivan J, SchmehI DR, Cabrera AR, Rangel J. Seasonal variation of pollen collected by honey bees (Apis mellifera) in developed areas across four regions in the United States. PLoS ONE. 2019;14:e0217294.

12. Cifuentes L. Allergy to honeybee... not only stings. Curr Opin Allergy Clin Immunol. 2015;15(4):364-8

13. Carlson G, Coop C. Pollen food allergy syndrome (PFAS): A review of current available literature. Ann Allergy Asthma Immunol. 2019;123:359-65.

14. Martín-Muñoz MF, Bartolome B, Caminoa M, Bobolea I, Ara MC, Quirce S. Bee pollen: a dangerous food for allergic children. Identification of responsible allergens. Allergol Immunopathol (Madr). 2010;38:263-5.

15. Tuncel $T$, Uysal $P$, Hocaoglu AB, Erge DO, Firinci F, Karaman O, Uzuner N. Anaphylaxis caused by honey ingestion in an infant. Allergol Immunopathol (Madr). 2011;39:112-3.

\section{Publisher's Note}

Springer Nature remains neutral with regard to jurisdictional claims in published maps and institutional affiliations.
Ready to submit your research? Choose BMC and benefit from

- fast, convenient online submission

- thorough peer review by experienced researchers in your field

- rapid publication on acceptance

- support for research data, including large and complex data types

- gold Open Access which fosters wider collaboration and increased citations

- maximum visibility for your research: over 100M website views per year

At BMC, research is always in progress.

Learn more biomedcentral.com/submissions 